\title{
Function of Power in Class Discourse
}

\author{
Jumadi \\ Universitas Lambung Mangkurat \\ jumswot@yahoo.com
}

\begin{abstract}
Power is the potentiality possessed by a person to influence the thoughts, feelings, and actions of others. In fact, power is used in all speech events, including in class discourse. Through speech acts and speech patterns, teachers (T) and students (S) use the power in learning activities. Generally, power in class discourse is used for preventive, supportive, and corrective action. Teachers use power for preventive action when preventing disciplinary offenses; misunderstanding of the subject matter; and other deviant behaviors in the learning process. Power is enabled for supportive actions when teachers motivate students to behave well, dare to ask questions, and answer when in the learning process. Meanwhile, when a violation of the rules happens, both school rules and rules in the learning process, the teacher uses the power of his authority to stop the offense. Generally, the use of power in class discourse still tends to be dominative. Although the teacher has been empowering the students in the learning process, but the source of power still tends to focus on the teacher. The teacher with his power still acts as the main determinant of rules and punishments in the learning process. Therefore, power has not been maximally utilized to lead students to participate actively in determining school rules, the various punishments to be borne, and the source of truth to the knowledge they are studying.
\end{abstract}

Keywords-- power, class discourse, and learning

\section{INTRODUCTION}

One of the functions of language is as a tool of power. In its function, the language provides elements that enable speakers to use speech acts and speech turn patterns to influence or even dominate the feelings, thoughts, and behaviors of others. These symptoms may occur in various speech events, whether in political, economic, social, or cultural institutions.

In discourse study, the fact can be justified. Fairclough (1998, p. 34), for example, states that power can occur in social class relationships, intergroup relationships within an institution, relationships between ethnic groups, between men and women, and between parents and children. In fact, van Dijk (1998, p. 5) shows that power can occur in all aspects of life, for example the military uses coercion to build up its power; parents use persuasive forms; professors and journalists use their knowledge, information, and authority; class, gender, and racial relationships often use hegemonic forms.

As one of the social institutions, class discourse is a domain that cannot be separated from the process of using power (Saville-Troike, 1994, p. 75). The use of power in this domain is influenced by the characteristics of class discourse. Fairclough $(1998$, p. 38) states that schools have a social and discourse order that involves the structure of a separate social space. It happens in many ways, namely, a set of situations of discourse, a set of social roles recognized by those who participate in the discourse, and a set of recognized goals for the discourse - learning, examination, and a set of social control. In these various contexts of authority, it seems that the use of power in class discourse is represented.

Until now there have been a number of studies on the use of power in class discourse. Jumadi (2010) examines the representation of power in the speech acts and communication patterns between teachers and students in class discourse. Abdullah and Hosseini (2012) in his research entitled Discursive Enactment of Power in Iranian High School EFL Classrooms concluded that teachers in the classroom play a dominant role so that students appear to be passive and helpless. This paper discusses the use of power in class discourse. This paper material discussion is focused on the nature of power, the use of power in class discourse, either for preventive, supportive, or corrective action.

\section{METHOD}

The experts have much to say about the nature of power. From the explanation, it does not always show similarity. Apparently, the difference in viewpoint will produce different explanations of power. Fairclough (1998, p. 295-296) tried to sort out the notion of power into two groups. The first and more general conception is power as a transformative capacity, the capacity of agents to influence the course of events. It means that the power can be both positive and repressive at the same time. The second, power is a rational conception, power over others and associated with domination by individuals or collectives.

From the axplanation above, it appears that power is interpreted from a dominative and humanist point of view. A dominative point of view usually describes power as something that tends to be repressive. On the contrary, a humanist point of view explains power as constructive. 
The explanation of the essentially repressive nature of power can be seen from Weber and his followers. Weber explains the power from traditional sociological concepts. Weber states that power is the possibility of coercing someone over the behavior of others, even opposite opposition. In line with Weber, Bachrach and Baratz claim that power determines others to obey (see Stone, 1986, p. 79). The formula shows that power always contains elements of coercion or elements that make others obey.

The explanation of power from a dominative point of view tends to place power in one center. Power always comes from top to bottom. Therefore, its spreading is always centered on those who are socially and institutionally superior to others. However, according to Foucault, power is not equivalent to traditional sociological concepts used with the same name because power is never empty of discourse. It means that power belongs not only to a privileged group but laso practiced duty or prohibition against those who do not have it (see Hall, 2001, p. 232-233).

For Foucault (in Hall, 2001, p. 232-233), power is everywhere; not because power covers everything, but because power itself comes from anywhere. Power may come from lower level, there is no twin opposition or covering everything between the one who has the power and the person who is the target of power. It seems appropriate to say that power relations have many special rights and take shape and influence the productive mechanism in various life sites.

The conception of power presented by Foucault appears to be based on a humanist point of view. In a humanist explanation, power does not always contain the elements of coercion and is centered on a particular social agent or group. Power is one's potential influence on the attitudes and behaviors of others (see Yukl, 1998, p. 165; Robbins et al., 1994, p. 521); or the potential to influence others for good or bad, be a gift or a whip (Lee, 2002, p. 28). From a humanist perspective, it can be drawn a number of basic characteristics of power, namely: (a) power is a potential possessed by a person / group, (b) the potential is in the form of influence, and (c) it can be positive or negative.

This basic characteristic indirectly leads to the existence of different kinds of power. In this context, experts also provide a diverse assimilation of power. Lee (2002) divides power over three types, namely (a) power built on coercion, (b) power built on benefits, and (c) power built on the principle of honor. If force power is used, people do it not to influence others, but to compel them to obey. In this case, obedience is achieved through threats, trickery, or physical coercion - whatever is done to arouse fear to the dominated part. The power of benefit is based on the assumption of exchange and the foundation of justice. Justice means that the parties involved in the interaction are equally worthy of the transaction. Meanwhile, the power of honor is based on respect, even love.

The classical grouping of power that has so far been followed by people is the kind of manipulation by Frech and Raven (see Yukl, 1998; Robbins et al., 1994; Gibson et al., 1996). Frech and Raven divide power into five types: power of coercion, legitimacy, prize, expertise, and reference.

\section{The Function of Power for Preventive Actions}

\section{FINDING AND DISCUSSION}

Class discourse is a learning domain designed and implemented to achieve a number of goals, both aim related to cognitive, affective, and psychomotoric aspects. Many factors are associated with achieving the goals, one of which is the use of power for preventive action.

The function of power for preventive action in harmony with the slogan is better to prevent than to cure. Froyen $(1993$, p. 59) states that the function of preventive power is intended to minimize the invasion of problems related to discipline. To perform the function, teachers usually anticipate it through planning. Estimating what tends to happen is an important element in the design and segregation of preventive measures.

The function for the prevention of disciplinary offenses is only one of the preventive functions of power. There are other functions revealed, such as functions to prevent the occurrence of concept errors, the carelessness in the lab, the obstacles in learning process, and other functions. In other words, the function of power in class discourse related to the efforts of teachers or students in designing and implementing learning to achieve goals on cognitive, affective, and psychomotoric aspects.

Power-preventive functions are commonly used by teachers in various contexts, including the context of briefing at the beginning of the semester, the context of classroom learning, and in the laboratory context. The function is realized by the delivery of rules, both rules related to the enforcement of discipline, the process of learning, the implementation of practicum, and completion of school tasks. The following quote shows the symptoms.

[1] T: If there is no change, I will be a homeroom teacher in this class.(1) Hopefully you all guys can work together well. (2) You are as a student and I am as a parent so when I get fussy later, please be advised. (3) [...] Hopefully you can also be good against other teachers. (4) Not only shown when I was as homeroom teacher. (5) I think it makes no difference to the homeroom teacher from other teachers (6) Well, to facilitate administrative activities and other financial, of course in class there must be class device, like class chairman, secretary. (7) Is there any class device already? (8)

S: Yes (student simultaneously replied). 
From the quotation [1] it seems that the teacher conveys the rules that the student should implement. Rule submission relates to the teacher's role as a homeroom teacher. Behind these roles are the responsibilities of homeroom teachers to foster their classes well. Usually, if there is a violation of the school rules by the students, especially the serious violations, the homeroom is directly responsible for the violation. Therefore, upon entering the beginning of the semester, the homerooms utilize their legitimate authority to prevent violations by conveying school rules. Thus, the sentence (1) to (8) indicates that the power of teachers functioned to prevent the class' violation occurrence of school rules he coached.

According to Froyen (1993, p. 54), the use of power for preventive purposes as mentioned above is inseparable from the image of teachers who are often regarded as in loco parentis, ie teachers as community representatives and as a chief of temporary household in the classroom. As representatives of the community and parents, of course the homeroom teacher and the teacher have the legitimate authority to prevent the occurrence of disciplinary offenses or other matters that are inconsistent with the educational and teaching measures. However, the strategy of delivering the rule still seems dominative. The class rules he gave were not excavated with the students. The rule substance tends to come from the homeroom teacher or the delivery strategy is still instructive, yet dialogical. Thus, power has not been enabled to empower students in preventing disciplinary offenses.

In a humanist learning system, the rule delivery tends to be dialogical. Students are involved to formulate the rules they will implement. Therefore, Dreikurs (in Cangelosi, 1993, p. 31) suggested that the delivery of class rules be democratic. The democratic act is characterized by (a) the student has a voice in determining the rules, (b) the student experiences the logical consequences of his misbehavior, and (c) the student is motivated to enforce the rules because of the advantages derived from the formulated rule.

The function of power in preventive action is expressed also in the teacher's speech when they carry out the learning process. In that context, the teacher tries to prevent negative things, such as misunderstanding the concept of a wrong particular learning material in its application. The following quote shows the symptoms.

[2] T: [...] Please keep in mind that national exam questions are usually statistic and they are not immediately known on the table, rarely. (1) It may be a question form like this, the story. (2) So you must remember that it is flat his datum is undergoing a change, yes, this means his standard deviation multiplied. (3) The standard deviation changes, and so does the datum, the average also changed.

In the quotation [2] it seems that teachers use their expertise to prevent misunderstanding of the learning material being explained. Teachers provide assertion, illustrations, examples so that students are not wrong in understanding a concept. In some contexts, it seems that some teachers use the expertise of other students to provide explanations. With certain guiding forms, the teacher guides the students to give explanations to other students. However, the symptoms are rarely done by the teacher. What often happens is that teachers directly function their power of expertise to provide an explanation of learning materials that are expected to lead to many misconceptions.

The preventive function of such power is also done by the teacher when giving direction to the students who will do the lab assignment in the laboratory. As it is understood that the laboratory contains easily damaged equipment and for a particular field of study contains harmful chemicals. Negligence in the implementation of the lab can certainly lead to damage and may harm the practitioner. Therefore, to prevent equipment damage and possible accident in practice, the teacher has the power of expertise. The symptoms appear in the following quotation.

[3] T: [...] This time we will do the lab. (1) Do not play around

in LAB. (2) How did you do this lab? (2) If

you do not read the procedure, you will not understand. (3) Do not

have a joke, it can break LAB equipment and so on. (4) When

using a microscope, you already knew in first grade, do not

until use a microscope, you still get a difficulty. (5) if you do not

understand, ask. (6) How about, is there any problem? (7)

$\mathrm{S}$ : (No one asks or asks questions).

The directive substance as shown in the quotation [4] is said by the teacher using a number of directive acts. Sentences (1), (4), and (5) are classified as directive actions with the form of prohibition. When viewed from its power illocution, the ban has high restriction levels. The restriction level is higher because the three restrictions use deontic modalities Do not. The prohibition characteristic with the use of modalities tends to represent the power of coercion in which the teacher functioned to prevent students' carelessness in doing practicum in a LAB.

To control the students' tasks, both individual and group tasks, the teachers also enable the power of preventive action. In this context, the teacher usually prevents errors from doing tasks, lack of serious task, uncompleted work, and delays in collecting tasks. 


\section{Function of Power for Supportive Actions}

Power can be enabled to encourage someone to behave or continue the positive behaviors having been demonstrated. Judging from the perspective of learning theory, one's behavior changes according to the consequences it causes. Pleasant consequences will reinforce behavior, while unpleasant consequences will weaken it. In other words, the fun consequences increase the same frequency of action, whereas unpleasant consequences decrease the frequency of a behavior (Slavin 2000, p. 146). Power can be enabled to provide positive consequences through the provision of motivation forms. The following quote is worthy of scrutiny.

[4] T: [...] Be a smart child! (1) If you are clever child, everything is easy. (2) Finding a school or a job, that's easy. (3) Your classmate whose name is Mita wins the LQ Prima quiz. (4) LQ Prima is the only champion getting 320 million. (4) Can you imagine, after graduating from the school, you can apply for job easily. (5) He is prioritized. (6) That is an example of a clever child's fate. (8)

S: (Students listen carefully).

In the quote [4], it seems that the teacher's actions are functioning as a tool to motivate students to be good students. Giving motivation is a form of gift power that enabled the teacher to encourage students to be smart children.

In the classroom discourse, supportive power functions are not only manifested by giving motivation, but also by reinforcing the positive behaviors shown by the students. The following quote shows the symptoms.

[5] S1: (Raise your hand to ask) May I, sir? (1)

T: Oh, do you want to ask? Yes, you may, please! (2)

$\mathrm{S}$ : In that piece, where's the bulkhead, sir? (3)

T: Well, this is such a good question. (4) Take a look! (5)

If that is not mentioned in the text, as usual it means in the piece that the bulkhead is considered to be on? (6)

S2: Air. (7)

T: On the air, right? (7) [...]

In the quote [5] it seems that teacher functions himself as the power of giving rewards to the courageous and able to ask the students well. In the speech (2), the teacher gives the widest opportunity to the students to ask questions; whereas in the speech (4) used by teachers to give positive response to the questions said by the students. Symptoms of the use of power as the two utterances are mostly done by the teacher, either when explaining the learning materials, guiding students to discuss, or ending the learning process.

In the perspective of learning theory, behaviors that are given positive reinforcement tend to be repeated. Even in the Social Learning Theory of Bandura, especially with regard to vicarious learning, the behavior of reinforced students will be imitated by other students (see Bigge 1982, p. 162-163; Dahar 1988, p. 37). Therefore, the provision of reinforcement is a learning element often done in the classroom discourse.

The use of prize power is also shown when the teacher does not judge the work result or student's appearance. In this context, although it sometimes gives criticism, it is constructive and empowering that encourages students to produce better works. The symptoms are indicated by the following quotation.

[6] T: [...] That title is no problem as well, the main point is suitable for the atmosphere. (1) It can be repaired later. (2) Then, if the word choice may still be simple, the poetic still does not exist. (3) However, the atmosphere, intonation, and inspiration are good. (4) [...] Voni, you've created, keep going, and do not stop. (5) Generally, it is getting good. (6)

$\mathrm{S}$ : (Students appear to be receiving feedback from teachers).

The quote [6] shows that the teacher appears to have enabled his legitimacy to have supportive action. The use of epistemic modalities, such as no problem, is good, keep going, do not stop, have started well in a number of these speeches represent the power of gift serving to encourage students to continue to create poetry. As we all know that most students in our schools still consider the specter of creating and reading poetry. The teacher's mistake in giving responses to students having the courage to create and read poetry in front of the class can exacerbate the symptoms. That is why, in the quotation, the teacher seems to still provide reinforcement as a tool to encourage students not to fear creating poetry. In fact, when viewed from the work and poetry readings that have been done by these students, the quality is not good as well.

\section{The Function of Power for Corrective Action}

Another function of power is to have a corrective action. According to Froyen (1993, p. 60), this function refers to efforts to discipline students who disobey the standards of responsible behavior. Teachers use this power function after students choose to avoid influencing them by overriding rules or procedures. Because the student's behavior is inappropriate, teachers refuse and punish, or at least remind them to reconstruct. 
In class discourse, the power function to have corrective action is used to correct disciplinary offenses, improve student's work, or other functions. The power function for disciplining students' actions is done so that students comply with all the rules that the school has established, whether written rules or conventions have developed in the world of schooling. Madsen and Madsen (1981, p. 7) provide two student's disciplinary characteristics, ie (a) the student learns to behave socially in an appropriate way, and (b) the student proves an appropriate response pattern to the academic task.

The use of power to correct disciplinary offenses can be seen in the following.

T: Good morning. (1)

S: Good morning. (2)

T: Take a quick look before our lesson starts! (3) I remind you, do not repeat again next time! (4) So, when the time has not come, do not leave the class without school permission! (5) If anything happens, then schools are blamed. (6) When I was in training, was there any task to do? (7)

S: Yes. (8)

T: Have you already done them all? (9)

S: It's hard, Mom. (10)

T: Difficult?, up to what number have you done? (11) [...]

From the above quote [7] it seems that teachers are reminding students of a class because they have broken the discipline by leaving school when the teacher is not in place. According to school rules, students may not leave school before the end of the day, except with the permission of the teacher or principal. Moreover, when it has given a task to do. Apparently, the problem has not been solved completely, even they have left the school. This kind of problem must be solved. To correct the disciplinary offense, teachers use sentences (4), (5), and (6) to warn them aloud.

The discipline enforcement done by the teacher is through the provision of punishment (Dahar, 1998, p. 31). In this context, the teachers use their legitimate authority to stop rule violations. The punishment type that teachers use is a penalty of moving or also called a time out penalty (Slavin, 2000, p. 151). According to Costenbader and RendingBrown research (see Slavin, 2000, p. 151), the use of moving penalty or time out can generally reduce bad mistakes.

According to some educational experts, the teacher's actions are worth doing. Even in certain contexts, teachers can use punishment as long as the punishment is still in the right way to educate them. If the teacher is permissive, the symptoms will precisely become a bad precedent in enforcing discipline in the classroom. According to Dreikurs (in Cangelosi, 1993, p. 31) permissive actions cause students to be confused and have no clear direction. Unterminated offenses are likely to be repeated by the same student and duplicated by other students.

In learning using discussion techniques, it needs to be supported by the students' ability to conduct discussions well. Discussion activities, in addition to requiring preparation, should also be sustained by the ability of presenters and discussion participants to run the discussion well. Discussion activities have mechanisms governing the flow of discussion execution. In order run the discussion effectively, the discussion participants should know and obey the mechanism of the discussion. Therefore, when in the discussion there are some students who violate discussion rules, teachers tend to enable their power to correct the violations. To clarify this exposure, the following quotation is worth noting.

[8] S: I would like to ask about the fish Jupiter planet takes place in ... (1)

$\mathrm{T}$ : Please, from what group is it? (2)

S: 1, I am Obsike from group 1 number 25 e ... 26. (3) I want to ask if it has recently been discovered a galaxy or a new solar system in the newspaper, similar to our solar system.

In the above quote [8] there is an interruption from a teacher because the student does not obey the rules of discussion about the previous discussions that the teacher has explained about the good questioning procedure in the discussion process, they are: asking in discussion should mention the name, and from which group the student is. However, in the above quote the student violates one of the rules of discussion. Through sentence (1), the student intends to directly address the question without complying with the rule. Therefore, through sentence (2), the teacher directly interrupts the student's speech. The interruption shows the legitimate authority of the teacher to correct the violation of the student's questioning rules.

Associated with the discussion, sometimes teachers also reprimand the students who ask or answer questions in an uncertainty and explain in a weak voice. The act of asking and answering questions of uncertainty and unclear sounds will disrupt the effectiveness of the discussion. Therefore, the teacher will always admonish the students if doing those things.

In the classroom discourse, power is also often used to stop students confusing the substance of learning. All teachers certainly do not want students to get confused about the substance of the learning described. However, due to lack of clarity of delivery, the limited capacity of students to capture the substance of learning, the difficulty level of 
learning substance, and the state of a rowdy environment, may cause students experiencing confusion capturing the substance of learning. The following quote shows the symptoms.

[9] T: Yes, three permutations two? (1) What is three permutations two? (2) Permutations, combination, permutation? (3) Are you confused? (4) Well, that's you. (5) So, if combination? (6)

S: 3 combinations 2. (7)

$\mathrm{T}$ : What is 3 combinations 2 ? (8)

S: 3. (9)

$\mathrm{T}: 3$, is it right? (10) Is possible event only three? (11)

S: $6 .(12)$

T: 6 ?, well, do you not remember? (13) So, if one currency is thrown, there may be number 2. (14) If any currency is thrown, this means if the first currency throws, what can this second currency partner can be with? (15)

From the above quotation, it seems that the teacher is functioning his power of expertise to stop students' confusion over the learning substance being described. According to the teacher, all the students' speeches are not correct in answering teacher's questions. The inaccuracy is because according to the teacher the students are confused and do not remember the formula that has been given. To overcome the confusion, the teacher uses speech (14), (15) as a means of providing the students with the aim of not being confused. From this study, the corrective function to stop such student's confusion is highly dominant in class discourse.

Discontinuation of students' confusion about the learning substance is not always done by the teacher. In some contexts, teachers use the power of other students to stop their friends' confusion. This method, of course, represents a more humanizing power than is directly done by the teacher. When among of them are stumble, the new teacher intervenes to overcome it. Apparently, the way in which the teacher did is preferred by many students. They feel involved to overcome the difficulties experienced by his friend. In fact, when teachers provide positive reinforcement by recording students who are involved in giving explanations, many students who participate trying provide an explanation. Thus, the function of power to stop student's confusion in understanding the learning substance can be done by teachers and also by students.

\section{CONCLUSION}

Overall, power in class discourse is used for preventive, supportive, and corrective action. The use of power in class discourse can be dominative and humanist. Therefore, in learning process, power can be exploited for coercive purposes and may also be used for productive purposes. Power exploited for coercive purposes tends to produce a dominative model of learning, while power utilized for productive purposes tends to create a humanistic learning model.

In a dominative learning model, students become the passive object of teacher's action. As a passive object, students are not required to participate actively in learning process because students are only filled by the teacher's words. Within the framework of this learning model, the teacher teaches students as if they were separated from the real life, as if the language of thought could exist without the reality (see Freire, 2002, p. 175).

Meanwhile, the humanistic learning model places the learning process as an effort to condition the students to know and express their true lifes in a critical way. To achieve it, according to Freire (2003, p. 103), the learning process is worthy of using dialogue as an option. In learning that prioritizes a dialogue, the teacher's role is to present the problem of existential situations that have been codified to help students to have a more critical view of reality. Philosophically, the responsibility of the teacher places himself more as a friend of the student's dialogue than simply removing the information that the student should remember.

In the future development, learning system in our education seems to be worthy of being directed towards developing a humanistic learning system. In a humanistic learning system, power is empowered as a means of maximizing students' potential in facing their future critically and creatively. By a humanistic learning system, our education is expected to anticipate the challenges of the XXI century education as proclaimed by UNESCO.

UNESCO has launched four pillars of education for XXI century education, namely learning to know, learning to do, learning to live together, and learning to be (see Delors et al., 1999). To realize the four pillars of education, power has a strategic function. Power can be empowered so that students are willing and able to do to master the instruments of knowledge (learning to know), both as a tool and purpose of life. As a tool, it enables everyone to understand at least enough about their environment to live dignitively, to develop their work skills and to communicate. As a goal, the basis is a passion to understand, to know, and to discover.

In addition, power should be empowered to encourage students to be able to act creatively in their environment (learning to do). In this context, related learning attempts to realize the question of how to teach children to practice 
what they have learned and which education can be adapted to future work if it is impossible to predict exactly how a job develops?

Power is also potentially utilized to encourage students to be able to participate and cooperate with others in all human activities (learning to live together). According to UNESCO, this type of learning may be one of the big issues in education today. The world today is often a world of disputes that belies the hopes that some citizens have placed on human progress. Therefore, the notion of nonviolent teaching in schools is laudable even if it is one of many tools to counter prejudices causing disputes.

In addition, power can also be utilized to maximize the full development of students - body and soul, intelligence, sensitivity, aesthetic sense, personal responsibility and spiritual values (learning to be). In this context, all students should be empowered to think independently and critically and make their own decisions to determine for them what is believed to be carried out in various life forms.

\section{References}

Abdullah, F.S \& Hosseini, K. (2014). Teacher-Student Discourse Brokerage and Classroom Engagement. International Journal of Humanities and Social Science, 4, (1), May 2014.

Bigge, M. (1982). Learning theories for teachers. New York: Harper \& Row, Publishers.

Cangelosi, J. S. (1993). Classroom management strategies: Gaining and maintaining students cooperation. New York: Longman.

Dahar, R. W. (1988). Teori-teori belajar. Jakarta: Departemen Pendidikan dan Kebudayaan.

Delors, J., et al. (1999). Belajar: Harta karun di dalamnya. Terjemahan oleh W. P. Napitupulu. Jakarta: Komisi Nasional Indonesia untuk UNESCO.

Fairclough, N. (1998). Language and power. London: Longman.

Freire, P. (2002). Politik pendidikan: Kebudayaan, kekuasaan, dan pembebasan. Terjemahan oleh Agung Prihanto dan Fuad Arif Fudianto. Yogyakarta: Pustaka Pelajar.

Froyen, L. A. (1993). Classroom management: The reflective teacher leader. New York: Macmillan Publishing Company.

Gibson, J. L. dkk. (1996). Organisasi, perilaku, proses. Terjemahan oleh Nunuk Adiarini. Jakarta: Binarupa Aksara.

Hall, S. (2001). Foucault: Power, Knowledge and Discourse. Dalam Margaret Wetherell dkk. (Eds), Discourse theory and practice: A reader. London: Sage Pulications.

Jumadi. (2010). Representasi power dalam wacana kelas: Kajian kekuasaan berdasarkan ancangan etnografi komunikasi dan pragmatik. Yogyakarta: Pustaka Prisma.

Krashen, S. D. (1987). Principles and practice in second language acquisition. London: Prentice-Hall International.

Lee, B. (2002). The power principle. Terjemahan oleh Arvin Saputra. Jakarta: Binarupa Aksara.

Masden, C. H. \& Masden, C. K. (1981). Teaching/dicipline: A positive approach for educational development. Boston: Allyn and Bacon, Inc.

Robbins, S. P. dkk., (1994). Organisational behavior: Concepts controversies \& applications. New York: Prentice Hall.

Saville-Troike, M. (1986). The ethnography of communication. Oxford: Basil Blackwell.

Slavin, R. E. (2000). Educational psychology: Theory and practice. Boston: Allyn and Bacon.

Stone, C. (1986). Power and Social Complexity. Dalam Robert J. Waste (Edit), Community power: Directions for future research. London: Sage Publications.

Van Dijk, T. A. (1998). Critical discourse. http:www.let.uva.nl/-teun/cda.html, diakses 25 Desember 1998.

Yukl, G. A. (1994). Kepemimpinan dalam organisasi. Terjemahan oleh Jusuf Udaya. Jakarta: Prenhallindo. 